\title{
Circular-Knitted Gloves and Mittens
}

\author{
A RECORDED VOLUNTARY STANDARD OF THE TRADE
}

\section{COMMODITY STANDARDS}

Simplified Practice Recommendations and Commercial Standards are developed by manufacturers, distributors, and users in cooperation with the Commodity Standards Division of the Office of Industry and Commerce, Bureau of Foreign and Domestic Commerce, and with the National Bureau of Standards.

The purpose of Simplified Practice Recommendations is to eliminate avoidable waste through the establishment of standards of practice for stock sizes and varieties of specific commodities that currently are in general production and demand. The purpose of Commercial Standards is to establish standard methods of test, rating, certification, and labeling of commodities, and to provide uniform bases for fair competition.

The adoption and use of a Simplified Practice Recommendation or a Commercial Standard is voluntary. However, when reference to a Commercial Standard is made in contracts, labels, invoices, or advertising literature, the provisions of the standard are enforceable through usual legal channels as a part of the sales contract.

A Simplified Practice Recommendation or a Commercial Standard originates with the proponent industry. The sponsors may be manufacturers, distributors, or users of the specific product. One of these three elements of industry submits to the Commodity Standards Division the necessary data to be used as the basis for developing a standard of practice. The Division, by means of assembled conferences or letter referenda, or both, assists the sponsor group in arriving at a tentative standard of practice and thereafter refers it to the other elements of the same industry for approval or for constructive criticism that will be helpful in making any necessary adjustments. The regular procedure of the Division assures continuous servicing of each effective Simplified Practice Recommendation and Commercial Standard, through review and revision, whenever, in the opinion of the industry, changing conditions warrant such action. Simplified Practice Recommendations and Commercial Standards are printed and made available by the Department of Commerce through the Government Printing Office and the Department of Commerce field offices.

UNITED STATES DEPARTMENT OF COMMERCE

Charles Sawyer, Secretary 


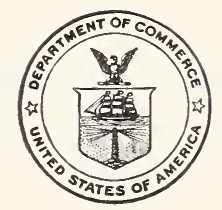

U. S. DEPARTMENT OF COMMERCE

Charles Sawyer, Secretary

BUREAU OF FOREIGN AND DOMESTIC COMMERCE

Office of Industry and Commerce

H. B. McCoy, Director

IN COOPERATION WITH

NATIONAL BUREAU OF STANDARDS

E. U. CONDON, DIRECTOR 


\title{
Circular-Knitted Gloves and Mittens
}

\author{
[Effective April 14, 1951]
}

\section{PURPOSE}

1.1. The purpose of this commercial standard is to provide standard methods of measuring, and standard measurements and tolerances for the guidance of producers, distributors, and users, in order to eliminate confusion resulting from a diversity of measurements and methods, and to provide a uniform basis for guaranteeing correct size.

\section{SCOPE}

2.1 This standard covers methods of measuring, and standard size measurements and tolerances for children's, misses', boys', cadets', women's, and men's circular-knitted gloves and mittens, made of wool or combinations of wool and other fibers, such as cotton, rayon, nylon, and the like. The standard also includes a recommended method of identification.

\section{APPLICATION}

3.1 The methods and measurements given herein are applicable to finished gloves and mittens as delivered by the manufacturer.

\section{GENERAL REQUIREMENTS}

4.1 Method of measuring.-The glove or mitten to be measured is laid out without tension on a smooth, flat surface.

4.2 Accuracy.-Measurements are taken to the nearest $1 / 10$ inch.

\section{METHODS OF MEASURING}

\subsection{Lengths.}

5.1.1 Cuff.-Measured from point where cuff joins body of glove at wrist to end of cuff. $C$, figure 1 .

5.1.2 Palm.-Measured from wrist to bottom of middle finger. $P$, figure 1.

5.1.3 Finger.-Measured from point where finger joins glove to end of finger. $F$, figure 1.

5.1.4 Hand.-Measured from wrist to end of middle finger. $\Pi$, figure 1.

5.1.5 Total.-Measured from lowest point of glove to tip of middle finger. $T$, figure 1 .

5.2 Width of glove.-Measured across glove at thumb crotch. W, figure 1 . 


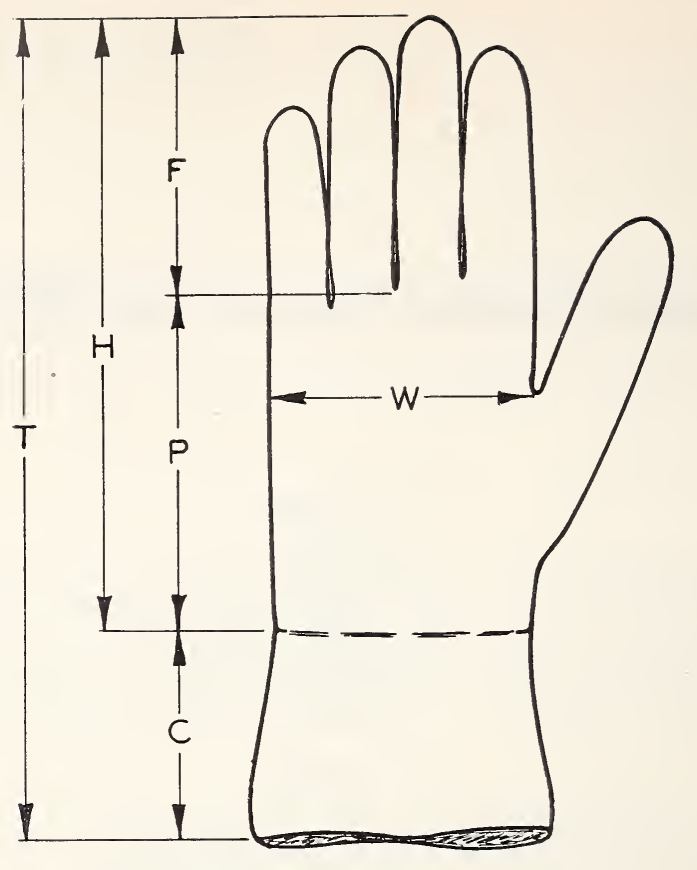

Figure 1. Knitted glore.

\section{STANDARD MEASUREMENTS}

6.1 Standard measurements and tolerances for children's, misses', boys', cadets', women's, and men's circular-knitted gloves (and mittens, wherever applicable) are shown in tables 1 and 2 .

TABLE 1. Standard measurements of circular-knitted gloves for children, misses, and boys ${ }^{1}$

\begin{tabular}{|c|c|c|c|c|c|c|c|c|c|c|}
\hline \multirow[b]{3}{*}{ Size designations... } & \multicolumn{9}{|c|}{ Classifications } & \multirow{3}{*}{$\begin{array}{l}\text { Toler- } \\
\text { ances } \\
\text { (plus or } \\
\text { minus) }\end{array}$} \\
\hline & \multicolumn{3}{|c|}{ Children } & \multicolumn{3}{|c|}{ Misses } & \multicolumn{3}{|c|}{ Boys } & \\
\hline & 1 & 2 & 3 & $4 \mathrm{Mi}$ & $5 \mathrm{Mi}$. & $6 \mathrm{Mi}$. & $4 B$ & $5 \mathrm{~B}$ & $6 \mathrm{~B}$ & \\
\hline Lengths: & Inches & Inches & Inches & Inches & Inches & Inches & Inches & Inches & Inches & Percent \\
\hline Cuff....$(C)$ & 2.2 & 2.2 & 2. 2 & 2.5 & 2.5 & 2.5 & 2.5 & 2.5 & 2.5 & 6 \\
\hline Palm__.... $(P)$ & 2.4 & 2. 6 & 2.9 & 3.2 & 3.6 & 3.9 & 3.2 & 3.6 & 3.9 & 6 \\
\hline Finger & 2.4 & 2.6 & 2.7 & 2.7 & 2.8 & 3.0 & 2.7 & 2.8 & 3.0 & 6 \\
\hline Hand & 4.8 & 5.2 & 5.6 & 5.9 & 6.4 & 6.9 & 5.9 & 6.4 & 6.9 & 6 \\
\hline Total & 7.0 & 7.4 & 7.8 & 8.4 & 8.9 & 9.4 & 8.4 & 8.9 & 9.4 & 6 \\
\hline Width of glove_ $(\mathrm{W})$ & 2.8 & 2.8 & 2.8 & 3.1 & 3.1 & 3.1 & 3.2 & 3.2 & 3.2 & 6 \\
\hline
\end{tabular}

1 These measurements, wherever applicable, are also for circular-knitted mittens. 
TABLE 2. Standard measurements of circular-knitted gloves for cadets, women, and men ${ }^{1}$

\begin{tabular}{|c|c|c|c|c|c|c|c|c|c|c|}
\hline \multirow[b]{3}{*}{ Size designations } & \multicolumn{9}{|c|}{ Classifications } & \multirow{3}{*}{$\begin{array}{l}\text { Toler- } \\
\text { ances } \\
\text { (plus } \\
\text { or } \\
\text { minus) }\end{array}$} \\
\hline & \multicolumn{3}{|c|}{ Cadets } & \multicolumn{3}{|c|}{ Women } & \multicolumn{3}{|c|}{ Men } & \\
\hline & $7 \mathrm{C}$ & $8 \mathrm{C}$ & $9 \mathrm{C}$ & $\mathrm{S}$ & M & $\mathrm{L}$ & $8 \mathrm{M}$ & $9 \mathrm{M}$ & $10 \mathrm{M}$ & \\
\hline Lengths: & Inches & Inches & Inches & Inches & Inches & Inches & Inches & Inches & Inches & Percent \\
\hline $\begin{array}{l}\text { Cuff } \\
\text { Palm } \\
\text { Finger }(C) \\
\text { Hand } \\
\text { Total } \\
\text { Width of glove_( }(W)\end{array}$ & $\begin{array}{l}2.5 \\
3.9 \\
3.0 \\
6.9 \\
9.4 \\
3.5\end{array}$ & $\begin{array}{l}2.5 \\
4.3 \\
3.1 \\
7.4 \\
9.9 \\
3.5\end{array}$ & $\begin{array}{r}2.5 \\
4.7 \\
3.2 \\
7.9 \\
10.4 \\
3.5\end{array}$ & $\begin{array}{l}2.7 \\
3.9 \\
3.0 \\
6.9 \\
9.6 \\
3.3\end{array}$ & $\begin{array}{r}2.7 \\
4.3 \\
3.1 \\
7.4 \\
10.1 \\
3.3\end{array}$ & $\begin{array}{r}2.7 \\
4.7 \\
3.2 \\
7.9 \\
10.6 \\
3.3\end{array}$ & $\begin{array}{l}2.5 \\
4.1 \\
3.3 \\
7.4 \\
9.9 \\
3.8\end{array}$ & $\begin{array}{r}2.5 \\
4.5 \\
3.5 \\
8.0 \\
10.5 \\
3.8\end{array}$ & $\begin{array}{r}2.5 \\
4.9 \\
3.7 \\
8.6 \\
11.1 \\
3.8\end{array}$ & $\begin{array}{l}6 \\
6 \\
6 \\
6 \\
6 \\
6\end{array}$ \\
\hline
\end{tabular}

1 These measurements, wherever applicable, are also for circular-knitted mittens.

\section{IDENTIFICATION}

7.1 In order to assure the purchaser that he is receiving gloves that comply with standard measurements, it is recommended that those manufactured to conform to such standard measurements be identified by a washable-ink stamp, sticker, tag, or other label attached to the glove or mitten carrying the following statement:

These gloves have been made to measurements that are in accordance with Commercial Standard CS175-51, as developed by industry and the trade under the procedure of the Commodity Standards Division, and issued by the U. S. Department of Commerce.

$$
\text { Or, more briefly- }
$$

Size conforms to CS175-51.

\section{EFFECTIVE DATE}

8.1 Having been passed through the regular procedure of the Commodity Standards Division, and approved by the acceptors hereinafter listed, this commercial standard was issued by the United States Department of Commerce, effective from April 14, 1951.

Edwin W. Ely, Chief, Commodity Standards Division.

\section{HISTORY OF PROJECT}

On April 25, 1950, the Association of Knitted Glove and Mitten Manufacturers requested the cooperation of the National Bureau of Standards in the establishment of a commercial standard for circularknitted gloves and mittens made of wool, or combinations of wool and other fibers such as cotton, rayon, nylon, and the like. The consensus. was that the measurements and tolerances submitted for incorporation in the standard had been in general use in the industry for a sufficient length of time to justify the belief that they should be incorporated in a nationally recognized standard.

Following receipt of the request, these measurements and tolerances were sent to representatives of key manufacturers, distributors, and consumers for comment and review. The general consensus was in 
favor of their adoption. Accordingly, the recommended standard was submitted to the trade for written acceptance on August 10, 1950. Having received acceptances in writing estimated to represent a satisfactory majority, an announcement was issued on February 14, 1951, that the standard would become effective for new production from April 14, 1951.

Project Manager: L. R. Gilbert, Commodity Standards Division, Office of Industry and Commerce.

Technical Adviser: Wm. D. Appel, Organic and Fibrous Materials Division, National Bureau of Standards.

\section{STANDING COMMITTEE}

The following individuals comprise the membership of the standing committee, which is to review, prior to circulation for acceptance, revisions proposed to keep the standard abreast of progress. Comment concerning the standard and suggestions for revisions may be addressed to any member of the committee or to the Commodity Standards Division, Office of Industry and Commerce, United States Department of Commerce, which acts as secretary for the committee.

LEoN F. Swears (chairman), Leon F. Swears, Inc., Johnstown, N. Y.

DEWEY Zwicker, Zwicker Knitting Mills, 410-418 N. Richmond Street, Appleton, Wis.

Richard Rockwell, Ashe Manufacturing Corp., 17 Washington Street, Rensselaer, N. Y.

Arthur Haber, D. C. Haber Knitting Co., 700 Stanton Avenue, Cleveland, Ohio.

Harry A. Moss, Jr., American Knit Handwear Association, Inc., 52-54 S. Main Street, Gloversville, N. Y.

T. L. Blanke, National Retail Dry Goods Association, 100 W. Thirty-first Street, New York, N. Y.

Hy Thron, National Textile Distributors Co., 320 Broadway, New York, N. Y. (representing Wholesale Dry Goods Institute).

W. W. EveretT, JR., Woodward \& Lothrop, Washington, D. C.

Mrs. Erxest H. Daniel, Broad Branch and Grant Roads NW., Washington, D. C. (representing General Federation of Women's Clubs).

Dr. Grace Gerard, Hunter College, 695 Park Avenue, New York, N. Y. (representing National Council of Women of the U. S.).

Mrs. Margaret H. Kixgsbury, U. S. Department of the Interior, Washington, D. C. 


\section{ACCEPTANCE OF COMMERCIAL STANDARD}

If acceptance has not previously been filed, this sheet properly filled in, signed and returned will provide for the recording of your organization as an acceptor of this commercial standard.

$$
\text { Date }
$$

Commodity Standards Division, Office of Industry and Commerce, U. S. Department of Commerce, Washington 25, D. C.

Gentlemen :

We believe that the Commercial Standard $175-51$ constitutes a useful standard of practice, and we individually plan to utilize it as far as practicable in the

production $^{1} \quad$ distribution ${ }^{1} \quad$ purchase $^{1} \quad$ testing $^{1}$

of circular-knitted gloves and mittens. We reserve the right to depart from it as we deem advisable.

We understand, of course, that only those articles which actually comply with the standard in all respects can be identified or labeled as conforming thereto.

Signature of authorized officer

(In ink)

(Kindly typewrite or print the following lines)

Name and title of above officer

Organization

Street address

City, zone, and State

${ }^{1}$ Underscore which one. Please see that separate acceptances are filed for all subsidiary companies and affiliates which should be listed separately as acceptor's. In the case of related interests, trade associations, trade papers, etc., desiring to record their general support, the words "General Support" should be added after the signature. 


\section{TO THE ACCEPTOR}

The following statements answer the usual questions arising in connection with the acceptance and its significance:

1. Enforcement.-Commercial standards are commodity specifications voluntarily established by mutual consent of those concerned. They present a common basis of understanding between the producer, distributor, and consumer and should not be confused with any plan of governmental regulation or control. The United States Department of Commerce has no regulatory power in the enforcement of their provisions, but since they represent the will of the interested groups as a whole, their provisions through usage soon become established as trade customs, and are made effective through incorporation into sales contracts by means of labels, invoices, and the like.

2. The acceptor's responsibility.-The purpose of commercial standards is to establish, for specific commodities, nationally recognized grades or consumer criteria, and the benefits therefrom will be measurable in direct proportion to their general recognition and actual use. Instances will occur when it may be necessary to deviate from the standard and the signing of an acceptance does not preclude such departures; however, such signature indicates an intention to follow the commercial standard, where practicable, in the production, distribution, or consumption of the article in question.

3. The Department's responsibility.-The major function performed by the Department of Commerce in the voluntary establishment of commercial standards on a Nation-wide basis is fourfold : first, to act as an unbiased coordinator to bring all interested parties together for the mutually satisfactory adjustment of trade standards; second, to supply such assistance and advice as past experience with similar programs may suggest; third, to canvass and record the extent of acceptance and adherence to the standard on the part of producers, distributors, and users; and fourth, after acceptance, to publish and promulgate the standard for the information and guidance of buyers and sellers of the commodity.

4. Announcement and promulgation.-When the standard has been endorsed by a satisfactory majority of production or consumption in the absence of active, valid opposition, the success of the project is announced. If, however, in the opinion of the standing committee or of the Department of Commerce, the support of any standard is inadequate, the right is reserved to withhold promulgation and publication. 
The organizations and individuals listed below have individually accepted this standard for use as far as practicable in the production, distribution, purchase, or testing of circular-knitted gloves and mittens. In accepting the standard they reserved the right to depart from it as they individually deem advisable. It is expected that articles which actually comply with the requirements of this standard in all respects will be regularly identified or labeled as conforming thereto, and that purchasers will require such specific evidence of conformity.

\section{ASSOCIATIONS}

(General Support)

American Knit Handwear Association, Gloversville, N. Y.

National Association of Leather Glove Manufacturers, Inc., Gloversville, N. Y National Association of Retail Clothiers \& Furnishers, Washington, D. C.

National Retail Dry Goods Association, New York, N. Y.

\section{FIRMS AND OTHER INTERESTS}

Abdalla's, Inc., Opelousas, La.

Ackshand Knitting Co., Inc., Ballston Spa, N. Y.

Adam, Meldrum \& Anderson Co., Buffalo, N. Y.

Advance Glove Manufacturing Co., Detroit, Mich.

Albany Knitting Co., Inc., Albany, N. Y. Allied Knitting Mills, New York, N. Y.

Alma Knitting Mills, Inc., Gloversville, N. $Y$.

Anderson, C. C., Stores Co., Boise, Idaho.

Ashe Manufacturing Corp., Rensselaer, N. Y.

Bailey Co., The, Cleveland, Ohio.

Baker Co., The, Minneapolis, Minn.

Baynes Store, Anderson, Ind.

Becopa Glove Mills, Inc., Yonkers, N. Y

Block, William H., Co., The, Indianapolis, Ind.

Boyce-Lazarus Co., Johnstown, N, Y

Boyd-Richardson Co., St. Louis, Mo

Brach's, Hastings, Nebr.

Bresse's Oneonta Department Store, Oneonta, N. Y.

Browne, J. A., Co., Houlton, Maine.

Calvin, C. G., Inc., Traverse City, Mich.

Capwell, H. C., Co., Oakland, Calif.

Century Glove Corp., Newark, N, J.

I avids', Inc., Moscow, Idaho.

Davis \& Co., Inc., Cambridge, Ohio.

Demery \& Co, Detroit, Mich.

Desmond's, Los Angeles, Calif.

District of Columbia, Govermment of the, Purchasing Division, Washington, D. C.

Efroymson \& Wolf, Inc., Indianapolis, Ind.

Elliot Glove Co., New York, N. Y

Erlanger Dry Goods Co., Canton, Ohio.

Fantle Bros. Co., Racine, Wis.

Figel Knitting Mills, Inc., Albany, N. Y.

Fischer, Charles, \& Sons, Co., Watertown, II is

Fownes Bros. \& Co., Inc., New York, N. Y. Franklin Simon \& Co., New York, N. Y.

Franklin Tru-Fit Glove Co., Chicago Ill.

Frederick \& Nelson Co., Seattle, Wash.

Freese's, Inc., Bangor, Maine.

Fresno Dry Groods Co., Inc., Fresno, Calif.

Gatelys Peoples Store, Chicago, IIl.

Glove Stores, Inc., Chicago, Ill

Gorin's, Inc., Boston, Mass.

Haber, D. C., Knitting Co., Cleveland, Ohio.

Harris, A., \& Co., Dallas, Tex.

Hart, L., \& Son Co., Inc., San Jose, Calif. Henshey's, Santa Monica, Calif.

Hink, J. F., \& Son, Berkeley, Calif.

Houghton \& Simonds, Claremont, N. H.

Howard \& Barber Co., The, Derby, Conn.

Hub, The, Baltimore, Md.
Industrial By-Products \& Research Co., Philadelphia, Pa.

Kemp's Store, Frederick, Md

Kirven, J. A., Co., Columbus, Ga.

Levee's, Vallejo, Calif

Levy Bros. Department Stores, Burlingame, Calif.

Liberty Stores, Inc., Lowell, Mass.

Lougee, Oscar A., Co., Laconia, N. H.

Mabley \& Carew Co., Cincinnati, Ohio.

Macy, R. H., \& Co., Inc., New York, N. Y.

Malr Knitting. Inc., Osage, Iowa.

Martin, T. S., Co., Sioux City, Iowa.

May Co., The, Cleveland, Ohio.

McCurdy \& Co., Inc., Rochester, N. Y.

Mellon Institute, Pittsburgh, Pa.

Niller \& Paine, Inc., Lincoln, Nebr.

Miller's, Inc., Knoxville, Tenn.

Myers Bros., Springfield, IIl.

Myers Department Store, Whittier, Calif.

Nelson's of Rome, Inc., Rome, N. Y.

O'Neil, M., Co.. The, Akron, Ohio.

Par Knitting Mills, Inc., Chicago, Ill.

Patzig Testing Laboratories, Des Moines, Iowa.

Pollard, A. G., Co., Lowell, Mass.

Priehs, John, Mercantile Co., Mt. Clemens, Mich.

Reliance Knitting Mills Co., New York, N. Y.

Rich's, Inc., Atlanta, Ga.

Roval Knitting Mills, Inc., Chicago, Ill.

Sakowitz Bros., Houston, Tex.

Salkin \& Linoff, Inc.. Minneapolis, Minn.

Sain's, Inc., Detroit, Mich.

Sand \& Siman, Inc. New York, N, Y.

Schear's Department Store, Evansille, Ind.

Schuessler Knitting Mills, Chicago, Ill.

Scotsmoor Co., Inc., Johnstown, N. Y.

S a ars, Roebuck \& Co., Chicago, Ill.

Shepard Co., The, Providence, R. I

Simon, Franklin, New York, N. Y.

Spokane Dry Goods Co., Spokane, Wash.

strek \& Co., Superior, Wis.

Star Knitting Co. La Crosse, IVis

Steiger, Albert, Co. Springfield, Mass.

Sternwild Knitting Mills, Inc., Yonkers, N. Y. (General support.)

Stewart \& Co., Baltimore, Md.

Stix, Baer \& Fuller Co., St. Louis, Mo.

Swears, Leon F., Inc., Johnstown, N. $\mathbf{Y}$.

Verran, H. E., Co.. Middlesboro, Ky.

Windsor Gloves, New York, N. Y.

Wineman's Department Store, Huntington Park. Calif.

Wolf Wile Co., Inc., Lexington, Ky.

Younker-Davidson's, Sioux City, Iowa

Zion's Cooperative Mercantile Institution, Salt Lake City, Utah.

Zwicker Knitting Mills, Appleton, Wis.

\section{U. S. GOVERNMEN'T AGENCIES}

Agriculture, Department of, Division of Purchase, Sales, and Traffic, Washington, D. C.

Army, Department of, Army Catalog Office, Alexandria, Va.

Commerce, Department of, Office of Industry and Commerce, Textile and Leather Division, Washington, D C.

Interior, Department of, Bureau of Indian Affairs, Washington, D. C.

Veterans" Administration, Washington, 
COMMERCIAL STANDARDS

CS No.

0-40. Commercial standards and their value to business.

1-42. Clinical thermometers.

2-30. Mopsticks.

3-40. Stoddard solvent.

4-29. Staple porcelain (all-clay) plumbing fixtures.

5-46. Pipe nipples: brass, copper, steel and wrought-iron.

6-31. Wrought-iron pipe nipples. Superseded by CS5-46.

7-29. Standard weight malleable iron or steel screwed unions.

8-41. Gage blanks.

9-33. Builders' template hardware.

10-29. Brass pipe nipples. Superseded by $\operatorname{cs} 5-46$.

11-41. Moisture regains of cotton yarns. 12-48. Fuel oils.

13-44. Dress patterns.

14-51. Boys' sport and dress shirt (woven fabrics) size measurements.

15-46. Men's pajama sizes (made from woven fabrics).

16-29. Wallpaper.

17-47. Diamond core drill fittings

1. 29. Hickory golf shafts.

19-32. Foundry patterns of wood.

20-49. Vitreous china plumbing fixtures.

21-39. Interchangeable g r o u n d-glass joints, stopcocks, and stoppers.

22-40. Builders' hardware (nontem-

23-30. Feldspar.

24-43. Screw threads and tap-drill sizes.

25-30. Special screw threads. Superseded by CS24-43.

26-30. Aromatic red cedar closet lining. 27-36. Mirrors.

28-46. Cotton fabric tents, tarpaulins and covers.

29-31. Staple seats for water-closet bowls.

30-31. ( Withdrawn).

31-38. Wood shingles.

32-31. Cotton cloth for rubber and $\mathrm{pr}$ roxylin coating.

33-43. Knit underwear (exclusive of rayon).

34-31. Bax case, and strap leather.

25-49. Hardwood plywood.

36-33. Fourdrinier wire cloth.

37-31. Steel bone plates and screws.

38-32. Hospital rubber sheeting.

39-37. ( Withdrawn).

40-32. Surgeons' rubber gloves.

41-32. Surgeons" latex gloves.

42-49. Structural fiber insulating board.

43-32. Grading of sulphonated oils.

44-32. Apple wraps.

45-48. Douglas fir plywood.

46-49. Hosiery lengths and sizes.

47-34. Marking of gold-filled and rolledgold-plate articles other than watchcases.

48-40. Domestic burners for Pennsylvania anthracite (underfeed type)

49-34. Chip board, laminated chip board. and miscellaneous boards for bookbinding purposes.

50-34. Binders board for bookbinding and other purposes.

51-35. Marking articles made of silver in combination with gold.

52-35. Mohair pile fabrics (100-percent mohair plain velvet, 100-percent mohair plain frieze, and 50 -percent mohair plain frieze)

53-35. Colors and finishes for cast stone

54-35. Mattresses for hospitals.

55-35. Mattresses for institutions.

56-49. Oak flooring.
CS No. Book cloths, buckrams, and impregnated fabrics for bookbind ing purposes except library bindings.

58-36. Woven elastic fabrics for use in overalls (overall elastic webbing),

59-44. Textiles-testing and reporting.

60-48. Hardwood dimension lumber.

61-37. Wood-slat venetian blinds.

62-38. Colors for kitchen accessories.

$63-38$. Colors for bathroom accessories.

64-37. Walnut reneers.

65-43. Methods of analysis and of reporting fiber composition of textile products.

66-38. Marking of articles made wholly or in part of platinum.

67-38. Marking articles made of karat gold.

68-38. Liquid hypochlorite disinfectant, deodorant, and germicide.

69-38. Pine oil disinfectant.

70-41. Phenolic disinfectant (emulsifying type) (published witl CS71-41)

71-41. Phenolic disinfectant (soluble type) (published with CS70-41)

72-38. Household insecticide (liquid spray type).

73-48. Old growth Douglas fir, Sitka spruce, and Western hemlock standard stock doors.

74-39. Solid hardwood wall paneling.

75-42. Automatic mechanical draft oil burners designed for domestic installations.

76-39. Hardwood interior trim and molding.

77-48. Enameled cast-iron plumbing fixtures.

78-40. Ground-and-polished lenses for sun glasses (published with CS79-40).

79-40. Blown, drawn, and dropped lenses for sun glasses (published with CS78-40)

so-41. Electric direction signal systems other than semaphore type for commercial and other vehicles subject to special motor vehicle laws (after market).

81-41. Adverse-weather lamps for rehicles (after market).

82-41. Inner-controlled spotlamps for vehicles (after market).

83-41. Clearance, marker, and identification lamps for vehicles (after market).

84-41. Electric tail lamps for rehicles (after market).

85-41. Flectric license-plate lamps for vehicles (after market).

86-41. Electric ston lomps for velic'es (after market).

87-41. Red electric warning lanterns

88-41. Liquid burning flares.

89-40. Hardwood stair treads and risers.

90-49. Power cranes and shovels.

91-41. Factory-fitted Douglas fir entrance doors.

92-41. Cedar, sypress and redwood tank stock lumber.

93-50. Portable electric drills (exclusive of high frequency).

94-41. Calking lead.

95-41. Lead pipe

96-41. Lead traps and bends.

97-42. Electric supplementary driving and passing lamps for vehicles (after market).

98-42. Artists' oil paints.

99-42. Gas floor furnaces-gravity circulating type.

100-47. Porcelain-enameled steel utensils. 
CS No.

101-43. Flue-connected oil-buirning space heaters equipped with vaporizing pot-type burners.

102- (Reserved for Diesel and fuel-oil engines.)

103-48. Rayon jacquard velour (with or without other decorative yarn)

104-49. Warm-air furnaces equipped with vaporizing type oil burners.

105-48. Mineral wool insulation for low temperatures.

106-44. Boys' pajama sizes (woven fabrics).

107-45. (Withdrawn)

108-43. Treading automobile and truck tires.

109-44. Solid-fuel-burning forced-air furnaces.

110-43. Tire repairs-vulcanized (passenger, truck, and bus tires)

111-43. Earthenware (vitreous-glazed) plumbing fixtures.

112-43. Homogeneous fiber wallboard.

113-51. Oil-burning floor furnaces equipped with vaporizing pot-type burners.

114-43. Hospital sheeting for mattress protection.

115-44. Porcelain-enameled tanks for domestic use.

116-44. Bituminized-fiber drain and sewer pipe.

117-49. Mineral wool insulation for heated industrial equipment.

118-44. Marking of jewelry and novelties of silver.

(E) 119-45.1 Dial indicators (for linear measurements ).

120-48. Standard stock ponderosa pine doors.

121-45. Women's slip sizes (woven fabrics).

122-49. Western softwood plywood.

123-49. Grading of diamond powder.

(E) 124-45.1 Master disks.

125-47. Prefabricated homes.

126-45. Tank mounted air compressors.

127-45. Self-contained mechanically refrigerated drinking water coolers.

128-49. Men's sport shirt sizes-woven fabrics (other than those marked with regular neckband sizes.)

129-47. Materials for safety wearing apparel.

130-46. Color materials for art education in schools.

131-46. Industrial mineral wool products, all types-testing and reporting.

132-46. Hardware cloth.

133-46. Woven wire netting.

134-46. Cast aluminum cooking utensils (metal composition).

135-46. Men's shirt sizes (exclusive of work shirts)

136-46. Blankets for hospitals (wool, and wool and cotton).

137-51. Size measurements for men's and boys' shorts (woven fabrics).
CS No.

138-4\%. Insect wire screening.

139-47. Work gloves.

140-47. Testing and rating convectors

141-47. Sine bars, blocks, plates, and fixtures.

142-51. Automotive lifts.

143-47. Standard strength and extra strength perforated clay pipe.

144-47. Formed metal porcelain enameled sanitary ware.

145-47. Testing and rating hand-fired hot water supply boilers.

146-47. Gowns for hospital patients.

$1+7-47$. Colors for molded urea plastics.

148-50. Men's circular flat- and rib-knit rayon underwear.

149-48. Utility-type house-dress sizes.

150-48. Hot-rolled rail steel bars (produced from Tee-section rails )

151-48. Body measurements for the sizing of apparel for infants, babies, toddlers and children (for the knit underwear industry).

152-48. Copper naphthenate wood-preservative (spray, brush, dip application).

153-48. Body measurements for the sizing of apparel for girls (for the knit underwear industry).

154- . (Reserved for wire rope).

155-50. Body measurements for the sizing of boss' apparel (knit underwear, shirts, trousers).

156-49. Colors for polystyrene plastics.

157-49. Ponderosa pine and sugar pine plywood.

158-49. Model forms for girls' apparel.

159-49. Sun glass lenses made of ground and polished plate glass thereafter thermally curved.

160-49. Wood-fiber blanket insulation (for building construction).

161-49. "Standard grade" hot-dipped galvanized ware (coated after fabrication).

162-49. Tufted bedspreads.

163-49. Standard stock ponderosa pine windows, sash, and screens.

164- . (Reserved for concrete mixers).

165-50. Zinc naphthenate wood-preservative (spray, brush, dip application).

166-50. Size measurements for men's work trousers.

167-50. Automotive and general service copper tube.

168-50. Polystyrene plastic wall tiles, and adhesives for their application.

169-50. Galvanized ware fabricated from pregalvanized steel sheets.

170-50. Cotton flour-bag (sack) towels.

171-50. Hardwood veneered doors.

172-50. Brass trim for water-closet bowls, tanks, and urinals (dimensional standards).

173-50. Heavy-duty alpha-cellulose-filled melamine tableware.

174-51. 140-F dry-cleaning solvent.

175-51. Circular-knitted gloves and mittens.

1 Where "(F)" precedes the CS number, it indicates an emergency commercial standard, drafted under war conditions with a view toward early revision.

NoTICE.-Those interested in commercial standards with a view toward accepting them as a basis of everyday practice may secure copies of the above standards, while the supply lasts, by addressing the Commodity Standards Division, Office of Industry and Commerce, U. S. Department of Commerce, Washington 25, D. C. 


\section{U. S. DEPARTMENT OF COMMERCE \\ Field Service}

Aibuquerque, N. Mex.

$203 \mathrm{~W}$. Gold Ave.

Atlanta 3, Ga.

50 Whitehall St. SW.

Baltimore 2, Md.

200 E. Lexington St.

Boston, Mass.

40 Broad St.

Buffalo 3, N. Y. 117 Ellicott St.

Butte, Mont.

306 Federal Bldg.

Charleston 29, S. C.

6 Hudson St.

Cheyenne, Wyo.

410 Federal Office Blug.

Chicago 1, Ill.

221 N. La Salle st.

Cincinnati 2, Ohio

105 W. Fourth st.

Cleveland 1t, Ohio

925 Euclid Ave.

Dallas 2, Tex.

1114 Commerce St.

Denver 2, Colo.

142 New Customhouse

Detroit 26, Mich. $230 \mathrm{~W}$. Fort St.

El Paso, Tex.

310 San Francisco St.

Hartford 1, Conn.

135 High St.

Houston 14, Tex.

602 Federal Office Bldg.

Jacksonville 1, Fla.

311 W. Monroe St.

Kansas City 6, Mo.

911 Walnut St.

Los Angeles 12, Calif. 312 N. Spring St.

Louisville 2, Ky.

631 Federal Bldg.
Memphis 3, Tenn.

229 Federal Bldg.

Miami 32, Fla.

36 NE. First St.

Milwaukee 2, Wis.

517 E. Wisconsin Ave.

Minneapolis 2, Minn.

607 Marquette Ave.

Mobile 10, Ala.

109-13 St. Joseph St.

New Orleans 12, La.

333 St. Charles Ave.

New York 4, N. Y.

42 Broadway

Oklahoma City 2, Okla.

102 NW. Third St.

Omaha 2, Nebr.

1319 Farnam St.

Philadelphia 6, Pa.

1015 Chestnut St.

Phoenix, Ariz.

sos N. First St.

Pittsburgh 22, Pa.

717 Liberty Ave.

Portland 4, Oreg.

$520 \mathrm{SW}$. Morrison St.

Providence 3, R. I.

327 Post Office Annex

Reno, Nev.

1479 Wells Ave.

Richmond 19, Va.

801 E. Broad St.

St. Louis 1, Mo.

1114 Market St.

Salt Lake City 1, Utah

109 W. Second, South

San Francisco 2, Calif. 870 Market St.

Savannah, Ga.

125-29 Bull St.

Seattle 4, Wash

909 First Ave.

For local telephone listing, consult section devoted to $U$. S. Government 